\title{
Assessment of the Relationship between Entrepreneurial Skills and Intentions - The Case of Vietnam
}

\author{
${ }^{1}$ Hien Mai Le, ${ }^{2}$ Thi Hong Lam Nguyen ${ }^{*}$ \\ ${ }^{1}$ TriNam Software Co Ltd., Vietnam \\ ${ }^{2}$ Thuongmai University, Vietnam
}

\begin{abstract}
At present, the nation start-up is considered as a national policy to innovate, exploit the intellectual, technological and new business models ... thereby creating more enterprise efficiency in many key industries, promoting the overall development of the economy. To become an entrepreneur, need to understand the start-up, the start-up process and most importantly, the skills you need to get started. Therefore, this article aims are to provide an overview of the start-up process and the relationship between different business skills, as well as how they relate to the students' intentions. A questionnaire survey was conducted among 92 students who had to study/graduated in Business Administration. The survey asked participants to rate themselves based on their creativity, ambiguity, marshaling, finance and self-efficacy skills. The results can help universities develop curricula that combine teaching skills to equip both the knowledge and skills needed for students or those who want to be successfully entrepreneurs.
\end{abstract}

Keywords: Skills, Intention, Business, Entrepreneurship.

\section{Introduction}

Entrepreneurship is a series of actions the act of design, launch and runs a business. Entrepreneurs are vital to every society as they keep competition high and prices low (Good, 2011). The term "Entrepreneur" is coined by Richard Cantillon in the book - "Essay on the Nature of Trade in General" for the first time in 1755 (Cantillon. R, 1892), is understood "as a risk-bearer, and the development of spatial economics". Many people, including students, have business ideas they want to work on but don't know where to start. As a result, government-sponsored startups are being implemented around the world. According to Echelon Magazine (Singapore), Vietnam currently has about 3,000 Innovative Startups (Innovation). This figure nearly doubled the estimate in 2015 (about 1,800 enterprises - published on the web: http://dean844.most.gov.vn). Starting in 2016, the government of Vietnam has approved the project "Supporting the national innovative start-up ecosystem to 2025 " to create a favorable environment to promote and support the process of forming and developing a type of enterprise with rapid growth based on the exploitation of intellectual property, new technology, business model.

Everyone can learn how to behave, how to see problems and skills, so entrepreneurship is a skill that can completely be broken down into a process to be able to teach and learn. The objective of this study is to provide an easy-to-understand overview of entrepreneurship and the relationship of individual attributes (skills) to that individual's intentions to start a business.

\section{Literature review}

\subsection{Entrepreneurial}

Starting a business is the process of identifying opportunities, planning resources and creating a new business to provide the products or services needed by the customer (Zimmerer and Scarborough, 2002). Entrepreneurship occurs all over the world but is a characteristic of a free market economy. According to GEDI (Global Entrepreneurship and Development Institute) has released a global startup index (GEI) - table 1, the countries with the highest startup rates are the United States, Switzerland, Canada, UK, Australia, Denmark, Iceland, Ireland, Sweden and France (GEDI, 2019). Vietnam ranked 73/137 countries surveyed. Besides, the survey results on startup skills also show that the United States, Australia, Korea, Slovenia, 
Barbados, Serbia, and Greece are the leading countries (reaching 1.000 points); Vietnam scored 0.252 at 85/137 countries (GEDI, 2019).

\section{Table 1: Global Entrepreneurship Index}

\begin{tabular}{|l|l|l|}
\hline Rank & Country & GEI \\
\hline 1 & United States & 86.8 \\
\hline 2 & Switzerland & 82.2 \\
\hline 3 & Canada & 80.4 \\
\hline 4 & Denmark & 79.3 \\
\hline 5 & United Kingdom & 77.5 \\
\hline 6 & Australia & 73.1 \\
\hline 7 & Iceland & 73.0 \\
\hline 8 & Netherlands & 72.3 \\
\hline 9 & Ireland & 71.3 \\
\hline 10 & Sweden & 70.2 \\
\hline & $\ldots \ldots$. & \\
\hline 73 & Vietnam & 26 \\
\hline
\end{tabular}

\section{(Source: Global Entrepreneurship Index, 2019)}

Entrepreneurship is one of the most important parts of any successful market economy: creating new products/services; introducing innovative methods; creating markets and growing or producing new products or services; providing job opportunities and creating jobs; paying income tax. Most entrepreneurs operate in the areas of small and/or family-owned businesses, which are significant drivers for economic growth in an economy. Being an entrepreneur has several advantages, such as the chance to be their own boss and to enjoy an independent lifestyle, do something that they are passionate about but in exchange, it requires a tremendous amount of personal time and commitment - particularly in the early stages of a new business startup or uncertainty of income and the potential for financial loss are also potential negatives. Therefore, to be successful, an entrepreneur must be able to endure and even thrive in risky and uncertain conditions. Successful business operations also require innovation and creativity, as well as confidence and high expectations. Many aspects that must come together to become a successful entrepreneur, including: the entrepreneur, opportunity, strategy, organization and resources (Good, 2011).

\subsection{Entrepreneurial skills}

Without business skills, starting a business can be difficult. Entrepreneurs can be filled with passion and have great ideas, but the reality is that pure passion is not enough to guarantee the success of a business. As stated previously, a successful entrepreneur holds both the right characteristics and the right business skills, not one or the other (George, 2001). The business skills that will be focused on in this research are creativity, ambiguity, self-efficacy, marshaling and financial skills.

\section{*Creativity skill}

To be creative in business is to be innovative, those two skills go hand in hand with each other. According to Siyana Sokolova (2015), innovation and creativity have become crucial skills for business success in developing economies. Creation is defined as "the act of turning new ideas and imagination into reality". Creativity is characterized by the ability to perceive the world in new ways, to find hidden patterns, make connections between seemingly unrelated phenomena, and create solutions (Naiman, 2014). While creativity is the ability to create new ideas, innovation is the act of executing those ideas. People come up with good 
ideas to solve problems but lack the thought process or know - how of how to make that idea practicality. Acquiring both skills and learning to balance them is key to starting a business.

The creativity is important for starting and running a business because it helps explore completely new and unknown territories that increases production of that organization (Sokolova, 2015). New businesses need to give their employees the chance to be creative to encourage creativity. For example, Google encourages creativity by implementing different communication channels like Google cafes, which are designed to encourage interactions between employees across teams or all employees can send direct emails to company leaders or " 20 percent" projects allow engineers to spend $20 \%$ of their workweek on something that interests them (Laura H., 2013). Creativity and innovativeness bring fresh perspectives and ideas, and having open communication channels shows the people you work with that you're listening and are open to their feedback (Laura H., 2013).

\section{*Ambiguity skill}

It takes a lot of courage to become an entrepreneur because the uncertainty is often associated with entrepreneurship. During operation, business is uncertain, verbal agreements are not always upheld, contracts may be terminated early, loyal clients and key customers may disappear without reason. Steven D. Strauss said that "as an entrepreneur, you do not know if your ideas will work, you do not know if you will get funded, you do not know where customers come from, you do not know what the competition will do- and that's just the beginning" (Strauss, 2013). Entrepreneurs need to be aware that the business doesn't always follow its plan, and ambiguity is a very important business skill to learn, that is, to commit to a decision at the same time looking for evidence to prove you are wrong. Strauss et al. used a quote from Donald Rumsfeld (speaking at a press conference on Afghanistan on February 12, 2002) to explain this: "Known knowns are things we know that we know. Known unknowns are things we know we do not know. But there are also unknown unknowns which are the thing we do not know we do not know". Entrepreneurs are creating something that doesn't exist, so ambiguity is one of the most important skills one can have (Strauss et el., 2013). Like other business skills, ambiguity can be learned, unfortunately, it is learned through the process of making mistakes early, cheaply, and often. It takes courage and a willingness to learn through trial and error in an entrepreneur's path to success.

\section{*Marshaling skill}

It is almost impossible to start a business with just one person. To start a business requires knowledge, ideas, experience, feedback and participation of many people. According to Banker (2017), signs of a good cofounder include: (1) Successful business partners should start with having a shared vision and mission; (2) Make sure each partner's needs and expectations are addressed; (3) Identify and utilize the strengths of each partner; (4) Support the partnership's limitations; (5) Set company and individual goals; (6) Handle disagreements, disappointments and frustrations early; (7) Define job roles for each partner, including accountability (Banker, 2017).

The other aspects of marshaling are networking and gathering new members. Fry (2016) identified that "creating new relationships and meeting new people is so important for new businesses because it helps to find new customers, partners and ultimately grow the business". Furthermore, getting to know others provides insight into what's going on or the industry standard in which you intend to do business as well as other factors that bring benefits to the business. Networking not only improves one's business but also increases confidence by talking to new people. Especially for small businesses, forming and maintaining a working network is crucial for growth.

\section{*Financial skill}

According to Investiopedia.com (2017) that: "Finance is understood as the management, creation and study of money, banking, credit, investments, assets and liabilities that make up financial systems, as well as the study of those financial instruments". Regardless of training, an entrepreneur must have at least some financial skills to run a successful business, otherwise, money will go in and out of the business without anyone ever knowing. One of the best tools, which is standard now for businesses, are financial statements. Unfortunately, just having these numbers is not going to solve cash flow problems. Entrepreneurs must know how to interpret and make sense of numbers in financial statements. Another useful financial skill is budgeting for a new project. Estimating a budget is done by looking at all the different types of expenses 
included in that project and is used to authorize a project. Costs typically include labor, materials, equipment, services, software, hardware, facilities, and contingency costs (Investiopedia.com, 2017).

Financial skills are not always innate and are mostly learned from experience. For example, a good financial analyst has a key talent for seeing patterns in data and the cause of effect between those data points. While Carol Morgan said that simple money management skills include making a budget, being a conscious consumer, balancing a checkbook, having goals and plans and looking for investment opportunities (Morgan C., 2017).

\section{*Self-efficacy skill}

Self-efficacy is defined as "a person's belief about his or her abilities and capacity to accomplish a task or to deal with the challenges of life" (Bandura, 2017). And Artino (2012) defined "self-efficacy is people's judgments of their capabilities to organize and execute courses of action required to attain designated types of performances". Not to be confused with self-esteem which is the confidence of one's worth or abilities, self-efficacy is the recognition of one's own abilities. It is being able to recognize what a person's strengths are, what they can do, and when they need help from others (Artino, 2012). According to Vyakarnam, Shailendra and Neal Hartman (2011), an individual must feel confident about their abilities when starting a new project. The level of self-efficacy in feasibility can range from very high to very low. People with very low self-efficacy often think that challenging tasks are beyond their capabilities and will avoid difficult tasks while those with higher self-efficacy view challenges as mastery, they will be more concerned about and have a deeper sense of the activities they engage in and quickly got up after each failure (Vyakarnam et al., 2011). Bandura A. (1997) stated that there are four main sources in which self-efficacy can be learned, including:

1. Experience: are the most effective as they provide direct, authentic evidence that an individual can gather the necessary resources for success. This means that if someone had a goal in the past and they learned to achieve that goal and overcome their challenges, their level of self-efficacy increases and are more likely to succeed in future missions.

2. Observing the successes and failures of others. The observation of others can push others to believe that they too can be successful through persistence and effort. However, observation is a less dependable source of information about one's own capabilities than is a personal experience. Therefore, self-efficacy that is based only on the observation of others is weaker and more susceptible to change (Artino, 2012).

3. The form of verbal persuasion. Verbal persuasion encourages other people to believe that they can overcome difficult challenges. So, verbal persuasion must be subtle and honest.

4. Possesses positive energy: Persons own physiological and emotional feedback during performance, particularly something that is involving physical activity. Emotions like anxiety can have a negative effect on performance so when they don't have a stress response, they tend to be successful.

\section{Research methods}

Based on the prior studies, to investigate the relationship between entrepreneurial intentions and entrepreneurial skills, this research has established hypothesis:

\section{$H_{0}$ (null hypothesis): There is no relationship between entrepreneurial skills and intentions}

\section{$H_{1}$ (alternative hypothesis): There is relationship between entrepreneurial skills and intentions}

To prove the above hypothesis, the authors used a questionnaire consists of 2 parts: (1) Part 1 asked some general questions, how involved they were with business and if they've had previous experience with business before ; (2) Part 2 consists questions that participants to rate themselves based on their creativity, ambiguity, marshaling, finance and self-efficacy skills as well as rate their attitudes towards starting a business themselves, different business characteristics such as leadership and persistence.

In the survey, respondents answer questions about entrepreneurial skills on a scale of 1 to $7 ; 1$ being I'm not good at this, and 7 beings I excel at this. There are five skill categories (creativity, ambiguity, marshaling, finance and self-efficacy) each with three questions. Questions about intentions are suggested to assess personal attitudes by a Likert-scale value of 1 to 7 ( $1=$ Strongly disagree; $7=$ I agree). The three statements 
the participants were asked to evaluate here were; my goal is to become an entrepreneur, I have business ideas that I want to implement and, I intend to start a business within the next three years.

Based on the study of Hair et al. (2011), the minimum sample size is calculated: $5 \times$ the total observed variables. Thus, the minimum sample size guaranteed for the study is $5 \times 18=90$ by the requirements set out and ensures the representativeness of the whole. The study used a random sampling method to select the sample include students who have or are studying business administration major at university in Vietnam through google docs and email. The total number of votes issued was 110, and the number of valid votes was 92 (accounting for 83.6\%).

Then the authors used IBM 20 SPSS software to calculate and analyzes mean, spearman correlation, pvalues to indicate the relationship between entrepreneurial skills and intentions.

\section{Results}

\subsection{The demographic characteristics}

Of the 92 surveyed people, most have university degrees (98.9\%) with $75 \%$ female and $25 \%$ male. Up to $34.8 \%$ of surveyors have ever conducted or engaged in business activity in the past.

$96.7 \%$ of people familiar with surveyed individuals such as parents or friends, relatives living with are currently working, of which $68.5 \%$ have a university degree or higher and only $38 \%$ have ever had a business (e.g. selling online ...). This rate is quite suitable for the respondents as the majority of respondents live in rural areas or towns (70.6\%) are less developed areas therefore, they do not understand and care about entrepreneurship. At the same time, the economic conditions of the survey subjects' families are only at an average level (in 2019 it was 180 million VND), leading to 63\% of respondents saying that they have no conditions to start a business shortly (6 months).

Nearly $20 \%$ of respondents have taken short-term entrepreneurship courses. $53.3 \%$ of respondents have ever participated in volunteering, $67.4 \%$ have worked overtime, $25 \%$ have been responsible for an activity or project outside of school and $23.9 \%$ have ever done activities and projects outside the school.

The study results of surveyed subjects were relatively good with $99.9 \%$ points from average or higher, of which more than $50 \%$ points above average.

The results of the demographic characteristics will affect the intention to start a business as well as the intention to equip skills for startup goals.

\subsection{Assess the relationship between entrepreneurship skills and intentions}

The result shows that:

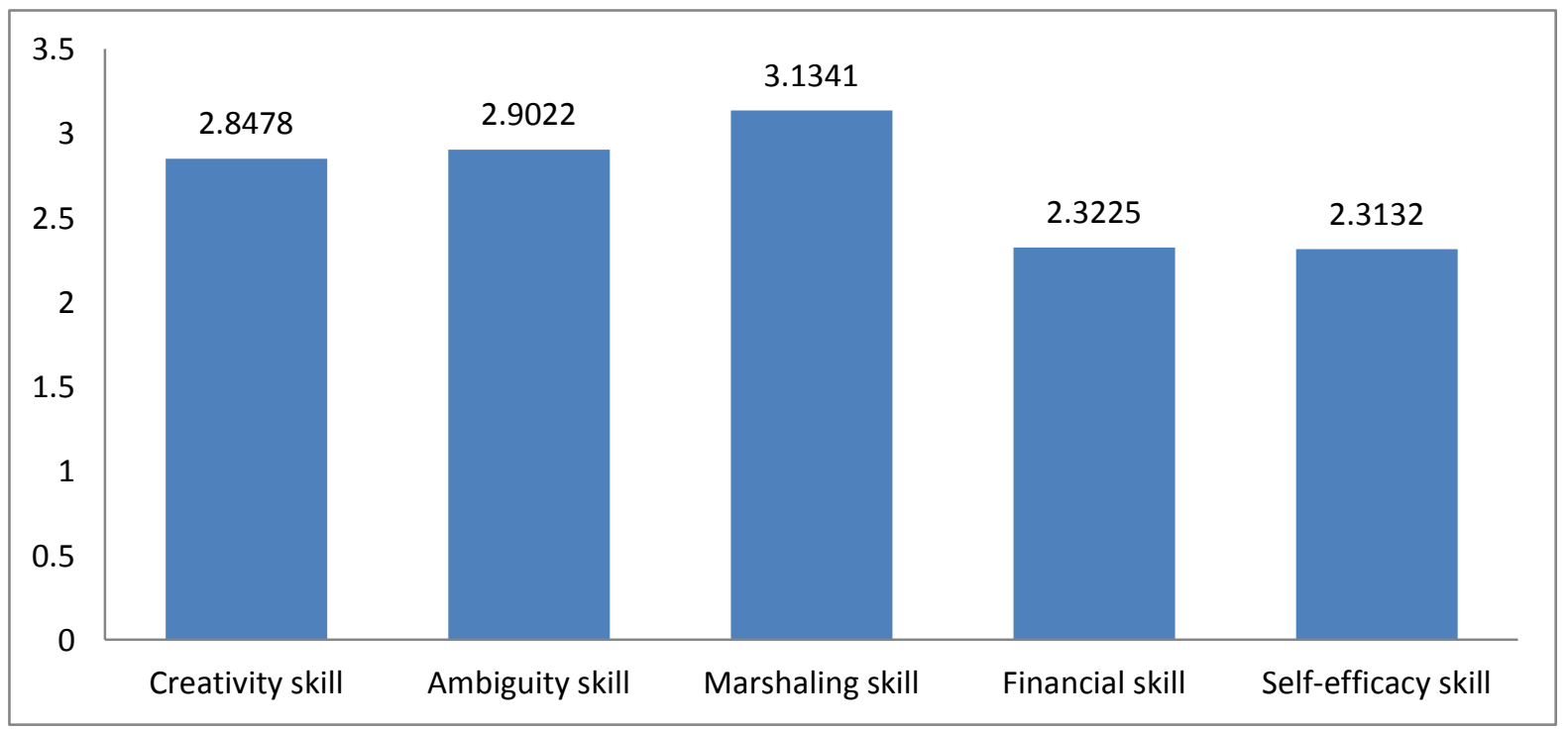

Diagram 1: Mean of entrepreneurship skills 
Diagram 1 shows the average (mean) of each skill. It can be seen that the necessary skills are below average $(<3.0)$ while the entrepreneurial attitude and spirit (intentions) are above average, with the Mean result $=$ 4.3185 .

Tables 2 to 6 present the results of the statistical relevance of skills with entrepreneurial intentions.

Table 2: The correlation between Creativity skill and entrepreneurial intentions

\begin{tabular}{|c|c|c|c|}
\hline \multicolumn{2}{|c|}{ Creativity / Entrepreneurial intentions } & $\mathbf{q} 23$ & q30 \\
\hline \multirow{3}{*}{ Spearman's rho } & Correlation Coefficient & 1.000 & .175 \\
\hline & Sig. (2-tailed) & & .099 \\
\hline & $\mathrm{N}$ & 92 & 90 \\
\hline Spearman's rho & Correlation Coefficient & .175 & 1.000 \\
\hline \multirow[t]{2}{*}{ q30 } & Sig. (2-tailed) & .099 & . \\
\hline & $\mathrm{N}$ & 90 & 90 \\
\hline
\end{tabular}

Spearman's correlation coefficient between creativity and entrepreneurial intentions is valued at $0.175(>0)$, means there is a correlation between creativity skill and their intention to start a business but the confidence level (p-value) is 0.099 , meaning that the obtained evidence is weak to confirm that correlation.

Table 3: The correlation between Ambiguity skill and entrepreneurial intentions

\begin{tabular}{|c|c|c|c|}
\hline \multicolumn{2}{|c|}{ Ambiguity / Entrepreneurial intentions } & q24 & q30 \\
\hline \multirow{3}{*}{ Spearman's rho } & Correlation Coefficient & 1.000 & .061 \\
\hline & Sig. (2-tailed) & & .568 \\
\hline & $\mathrm{N}$ & 92 & 90 \\
\hline spearman s rno & Correlation Coefficient & .061 & 1.000 \\
\hline \multirow[t]{2}{*}{ q30 } & Sig. (2-tailed) & .568 & \\
\hline & $\mathrm{N}$ & 90 & 90 \\
\hline
\end{tabular}

Regarding ambiguity skill, Spearman's correlation coefficient $=0.61$ and p-value $=0.568(>0.1)$, means that this skill is not statistically related to entrepreneurial intentions, which may reflect the interviewee's assessment of startup uncertainty, therefore the entrepreneurship is not uncertain.

Table 4: The correlation between Marshaling skill and entrepreneurial intentions

\begin{tabular}{|c|c|c|c|}
\hline \multicolumn{2}{|c|}{ Marshaling skill and entrepreneurial intentions } & $\mathbf{q} 25$ & q30 \\
\hline \multirow{3}{*}{ Spearman's rho } & Correlation Coefficient & 1.000 & .112 \\
\hline & Sig. (2-tailed) & & .294 \\
\hline & $\mathrm{N}$ & 92 & 90 \\
\hline speantman s 1 ino & Correlation Coefficient & .112 & 1.000 \\
\hline \multirow[t]{2}{*}{ q30 } & Sig. (2-tailed) & .294 & \\
\hline & $\mathrm{N}$ & 90 & 90 \\
\hline
\end{tabular}


About marshaling skill, Spearman's correlation coefficient $=0.112$ and $p$-value $=0.294(>0,1)$, meaning that this study did not find enough evidence to prove that marshaling skills and startup intentions variables are statistically dependent, reflect surveyed people's perceptions of marshaling skill that were not appreciated.

Table 5: The correlation between Financial skill and entrepreneurial intentions

\begin{tabular}{|c|c|c|c|}
\hline \multicolumn{2}{|c|}{ Marshalling skill and entrepreneurial intentions } & $\mathrm{q} 26$ & q30 \\
\hline \multirow{6}{*}{ Spearman's rho } & Correlation Coefficient & 1.000 & $.223^{*}$ \\
\hline & Sig. (2-tailed) & & .035 \\
\hline & $\mathrm{N}$ & 92 & 90 \\
\hline & Correlation Coefficient & $.223^{*}$ & 1.000 \\
\hline & Sig. (2-tailed) & .035 & \\
\hline & $\mathrm{N}$ & 90 & 90 \\
\hline
\end{tabular}

For financial skills, the Spearman correlation result is 0.223 ; the p-value is 0.035 , meaning there is a low average correlation between financial skills and startup intentions.

Table 6: The correlation between Self-efficacy skill and entrepreneurial intentions

\begin{tabular}{|c|c|c|c|}
\hline \multicolumn{2}{|c|}{ Self-efficacy skill and entrepreneurial intentions } & q27 & q30 \\
\hline \multirow{6}{*}{ Spearman's rho } & Correlation Coefficient & 1.000 & $.268^{*}$ \\
\hline & Sig. (2-tailed) & & .011 \\
\hline & $\mathrm{N}$ & 91 & 90 \\
\hline & Correlation Coefficient & $.268^{*}$ & 1.000 \\
\hline & Sig. (2-tailed) & .011 & . \\
\hline & $\mathrm{N}$ & 90 & 90 \\
\hline
\end{tabular}

With self-efficacy skill, the Spearman correlation coefficient is 0.268 ; p-value of 0.011 means there is a low average correlation between Self-efficacy skill and startup intentions, and a very high degree of self-efficacy skill. It can be seen that if people value themselves as highly self-efficacy skill, they are more likely to start their own businesses than those with low skills.

In summary, the survey results show that: The results are positive (highlighted in the table), meaning there is a statistical correlation between entrepreneurial skills and entrepreneurial intentions... In other words, according to the respondents, when having the intention to start a business or forming a start-up intention, it is necessary to have the above startup skills. However, the probability reliability is not the same, meaning that the importance of skills to the entrepreneur is different according to the subjective assessment of the survey subjects.

\section{Conclusion}

The article has summarized the essentials for starting an entrepreneur and at the same time analyzing the ability of skills to be learned to help with the training of entrepreneurship or professional training for advanced students to meet the needs of businesses. Furthermore, the survey results may partly reflect the general perception of young entrepreneurs about the skills they acquire during/after study. For universities specializing in Business Administration or economics: increasing the organization of skills training classes (maybe short-term in clubs) or content related to entrepreneurial skills in subjects of entrepreneurship, business administration. Strengthen links with businesses, professional organizations organize seminars, exchange, and explain skills to students or organize business tours, practical internships at enterprises to help students observe, learn and practice entrepreneurship skills and launch entrepreneurial intentions. For 
students: actively study, learn knowledge and practice skills necessary for entrepreneurship such as attending short-term entrepreneurship courses or joining experience clubs.

The limitation of the article is that the survey object is not wide enough, mainly focuses on students who lack some necessary knowledge and skills; inability to self-determine startup related issues. Therefore, in the future, it is possible to expand research with a larger number of samples and a wider audience, the results will be more accurate and highly effective for the individual surveyed, for the training schools and also as a suggestion for policy-makers. "The world needs more entrepreneurs and has better quality because our world problems are becoming more intense, complex, and pervasive"(Aulet 2013)./.

\section{References}

[1.] Artino, A.R. (2012). Academic self-efficacy. retrieved from: https://www.ncbi.nlm.nih.gov/pmc/articles/PMC3540350

[2.] Bandura A. (1997). Self-efficacy: the exercise of control. New York: W. H. Freeman and Company

[3.] Banker M. (2017). 7 Tips for a Successful Business Partnership. retrieved from: https://www.businessknowhow.com/startup/partnership-tips.html

[4.] Cantillon R. (1892). Essay on the Nature of Trade in General: A Variorum Edition (Routledge Studies in the History of Economics) 1st Edition. Reprinted for Harvard University

[5.] George M. (2001). Important Entrepreneurial Business Skills. Aveta Limited. retrieved from: https://www.sixsigmaonline.org/six-sigma-trainingcertification-information/importantentrepreneurial-business-skills/

[6.] Good Walter S. (2011). Building a dream: A Canadian Guide to starting your own business. 8th edition, McGraw-Hill Ryerson.

[7.] Hair, J. F., Ringle, C. M. \& Sarstedt. M. (2011). PLS-SEM: Indeed, a silver bullet. Journal of Marketing theory and Practice. Vol 19(2). pp 139-152.

[8.] K.Fry (2016). Why Networking is Important for Small Business. retrieved from: http://www.olympiabenefits.com/blog/why-networking-is-importantfor-small-business

[9.] Laura H. (2013). Google's Secrets Of Innovation: Empowering Its Employees. retrieved from: https://www.forbes.com/sites/laurahe/2013/03/29/googles-secrets-of-innovationempowering-itsemployees/\#5f2a79a557e737

[10.] Morgan C. (2017), 7 Simple Steps to Improve Your Financial Management Skills, retrieved from: https://www.lifehack.org/296492/7-simplesteps-improve-your-financial-management-skills

[11.] Naiman L. (2014). What is Creativity? retrieved from: https://www.creativityatwork.com/2014/02/17/what-is-creativity/

[12.] Siyana Sokolova (2015). The Importance of Creativity and Innovation in Business. retrieved from: https://www.linkedin.com/pulse/importance-creativityinnovation-business-siyana-sokolova

[13.] Strauss, Steven D., David Drake, Nikhil Agarwal, Baybars Altuntas, Tugrul Atamer, Thais Corral, Laurel Delaney, Jeannie Javelosa, and Anna-Lena Johansson (2013), Planet Entrepreneur, edited by Steven D. Strauss, et al., John Wiley \& Sons, Incorporated.

[14.] The 5 Traits of Top Financial Analysts (2016). Retrieved from: https://findingclarity.ca/blog/the-5traits-of-top-financial-analysts.

[15.] Vyakarnam, Shailendra, and Neal Hartman (2011). Unlocking the enterpriser inside. World Scientific Publishing Company.

[16.] Zoltán J. Ács, László Szerb, Esteban Lafuente, Gábor Márkus (2019). Global Entrepreneurship Index. retrieved from: http://thegedi.org/global-entrepreneurship-and-development-index https://www.investopedia.com/terms/f/finance.asp https://www.investopedia.com/terms/f/financial-statements.asp http://www.olympiabenefits.com/blog/why-networking-is-importantfor-small-business http://www.businessdictionary.com/definition/self-efficacy.html http://dean844.most.gov.vn 